\title{
ESTIMATION OF FRACTURES ORIENTATION FROM qP REFLECTIVITY USING MULTIAZIMUTHAL AVO ANALYSIS
}

\author{
Ellen N. S. Gomes, Jessé C. Costa, ${ }^{2}$ João dos S. Protázio, ${ }^{3}$ Ivan A. Simões Filho ${ }^{4}$ \\ Recebido em 3 jun., 2002 / Aceito em 5 dez., 2003 \\ Received Jun 3, 2002 / Accepted Dec. 5, 2003
}

\section{ABSTRACT}

We investigate the estimation of fractures orientation, strike and dip, through multiazimuthal AVO analysis of $q P$ and its converted waves $q S_{1}$ and $q S_{2}$. We assume weak impedance contrast, weak anisotropy and that the fractured medium behaves as an effective transversally isotropic (TI) medium. Under these assumptions, the estimation of fractures orientation is reduced to the estimation of the orientation of an axis of symmetry from $q P$ reflectivity data. Linearized approximations of $q P$ reflectivity are used for inversion.

Keywords: Anisotropy, fractures orientation, Multiazimuthal AVO.

\section{RESUMO}

Investigamos a estimativa da orientação de fratura; mergulho e direção, através da análise de AVO multiazimutal de ondas qP e de suas convertidas q $S_{1}$ e q $S_{2}$. Assumimos fraco contraste de impedância, fraca anisotropia e ainda que, o meio fraturado comporta-se efetivamente como um meio transversalmente isotrópico (TI). Dentro destas hipóteses, a estimativa da orientação de fratura reduz-se a estimativa da orientação do eixo de simetria a partir de dados de refletividade de ondas $q P$. Aproximações lineares da refletividade da onda $q P$ são utilizadas na inversão.

Palavras-chave: Anisotropia, estimativa da orientação de fratura, AVO multiazimutal.

Departamento de Matemática, Campus de Castanhal - Universidade Federal do Pará (UFPA), Rua Augusto Correa, $\mathrm{n}^{0}$ 1, Bairro do Guamá, CEP: 66075-900, Belém-PA. Departamento de Geofísica. Fax: 91-3183-1693, Tel: 91-3183-1692. E-mail: ellensg@ufpa.br.

2 Departamento de Geofísica - Universidade Federal do Pará (UFPA), Rua Augusto Correa, $n^{0}$ I, Bairro do Guamá, CEP: 66070-110, Belém-PA. Fax: 91-3184-1693, Tel: 91-3184-1692. E-mail: jesse@ufpa.br.

3 Departamento de Matemática - Universidade Federal do Pará (UFPA), Rua Augusto Correa, $n^{0}$ 1, Bairro do Guamá, CEP: 66075-900, Belém-PA. Departamento de Geofíisca. Fax: 91-31831693, Tel: 91-3183-1692. E-mail: protazio@ufpa.br.

4 Gaffney, Cline and Associates. 1360 Post Oak Blvd. suite 2500. Houston, TX 77056.Tel + 1-713-850-9955. Fax + 1-713-850-9966 E-mail: iadsf@attglobal.net 


\section{INTRODUCTION}

Most hydrocarbon reservoirs occur in fractured formations. In this case, fractures mainly control the reservoir permeability. Since wave propagation in fractured media might be modelled through an effective anisotropic medium (HUDSON, 1982; SCHOENBERG; SAYERS, 1995), the characterization of the reservoir elastic anisotropy from seismic data may help optimizing oil recovery. Previous works report fractures characterization from AVO/AVD data. Rüger and Tsvankin (1997) show how to estimate vertical fractures strike and fluid content information from $q P$ reflection coefficients data. Perez e outros (1999) use shear wave splitting and $P$ wave reflection data to determine the strike of a vertical set of fractures. Beretta, Bernasconi and Drufuca (2002) use diffraction tomography to estimate the fractures density also for vertically fractured medium. We formulate the problem of fractures characterization using the reflections coefficients of a $q P$ incident wave, including converted waves.

\section{FORWARD PROBLEM}

Consider weak impedance contrast and weak anisotropic media separated by a plane interface, $x_{3} \quad 0$. The incident and reflected waves propagate at the upper medium and the transmitted waves propagate through the lower medium. The linearized $q P$ reflectivity across an interface was presented by Gomes e outros (2001). The two anisotropic media are considered as small perturbations around an isotropic homogeneous background. The linear approximations are:

$$
\begin{aligned}
& R_{q P q P}=\frac{1}{2 \rho^{\circ} \alpha^{2}}\left\{\left[\Delta C_{11} \cos ^{4} \varphi+\Delta C_{22} \sin ^{4} \varphi+2 \Delta\left(C_{12}+2 C_{66}\right) \cos ^{2} \varphi \sin ^{2} \varphi+\right.\right. \\
& \left.4 \Delta C_{16} \cos ^{3} \varphi \sin \varphi+4 \Delta C_{26} \cos \varphi \sin ^{3} \varphi\right] \tan ^{2} \theta \sin ^{2} \theta+2\left[\Delta\left(C_{13}+2 C_{55}\right)\right. \\
& \cos ^{2} \varphi+\Delta\left(C_{23}+2 C_{44}\right) \sin ^{2} \varphi+\Delta\left(C_{36}+2 C_{45}\right) \sin 2 \varphi-4\left(\Delta C_{55} \cos ^{2} \varphi+\right. \\
& \left.\left.\left.\Delta C_{44} \sin ^{2} \varphi+\Delta C_{45} \sin 2 \varphi\right)\right] \sin ^{2} \theta+\Delta C_{33} \cos ^{2} \theta\right\}+\left(1-\frac{1}{2 \cos ^{2} \theta}\right) \frac{\Delta \rho}{\rho^{\circ}} \\
& R_{q S_{1} q P}=\frac{1}{2 \rho^{\circ} \alpha^{2} \eta(\theta)}\left\{2 \left[\Delta C_{11} \cos ^{4} \varphi+\Delta C_{22} \sin ^{4} \varphi+2 \Delta\left(C_{12}+2 C_{66}\right) \cos ^{2} \varphi \sin ^{2} \varphi+4\right.\right. \\
& \left.\Delta C_{16} \cos ^{3} \varphi \sin \varphi+4 \Delta C_{26} \cos \varphi \sin ^{3} \varphi+\right] \sin ^{3} \theta+2\left[\Delta\left(C_{13}+2 C_{55}\right) \cos ^{2} \varphi+\right. \\
& \Delta\left(C_{23}+2 C_{44}\right) \sin ^{2} \varphi+2 \Delta\left(C_{36}+2 C_{45}\right) \sin 2 \varphi-4\left(\Delta C_{55} \cos ^{2} \varphi+\Delta C_{44} \sin ^{2} \varphi+\right. \\
& \left.\left.\Delta C_{45} \sin 2 \varphi\right)\right] \sin \theta \cos 2 \theta-\Delta C_{33} \sin 2 \theta \cos \theta+\frac{1}{\kappa K(\theta)}\left\{2 \left[\Delta C_{14} \cos ^{2} \varphi \sin \varphi+\right.\right.\text { (2) } \\
& \Delta C_{15} \cos ^{3} \varphi+\Delta C_{24} \sin ^{3} \varphi+\Delta C_{25} \cos \varphi \sin ^{2} \varphi+\Delta C_{46} \sin \varphi \sin 2 \varphi+\Delta C_{56} \cos \varphi \\
& \sin 2 \varphi] \sin ^{2} \theta(2 \kappa \omega(\theta)-1)+2\left[\Delta C_{35} \cos \varphi+\Delta C_{34} \sin \varphi\right] \cos \theta(\cos \theta-2 K(\theta) \omega(\theta))+ \\
& \left.\left.2\left[\Delta C_{55} \cos ^{2} \varphi+\Delta C_{44} \sin ^{2} \varphi+\Delta C_{45} \sin 2 \varphi\right] \sin 2 \theta\left(\kappa^{2} \sin ^{2} \theta-K^{2}(\theta)\right)\right\}\right\}- \\
& \left(\frac{\sin \theta}{K(\theta)}\right) \frac{\Delta \rho}{\rho^{\circ}} \\
& R_{q S_{2 q} P}=\frac{1}{\rho^{\circ} \alpha^{2} K(\theta)}\left\{\frac { 1 } { \kappa } \left\{\left[\Delta C_{14} \cos ^{3} \varphi-\Delta C_{25} \sin ^{3} \varphi+\left(\Delta C_{24} \sin \varphi-\Delta C_{15} \cos \varphi\right) \cos \varphi\right.\right.\right. \\
& \left.\sin \varphi+\left(\Delta C_{46} \cos \varphi-\Delta C_{56} \sin \varphi\right) \sin 2 \varphi\right] \sin ^{2} \theta+\left[\Delta C_{45} \cos 2 \varphi+\Delta C_{44} \cos \varphi\right. \\
& \left.\left.\sin \varphi-\Delta C_{55} \cos \varphi \sin \varphi\right] \sin 2 \theta+\left[\Delta C_{34} \cos \varphi-\Delta C_{35} \sin \varphi\right] \cos ^{2} \theta\right\}-\frac{1}{\eta(\theta)} \\
& \left\{\left[\Delta C_{16} \cos ^{2} \varphi\left(\cos ^{2} \varphi-3 \sin ^{2} \varphi\right)+\Delta C_{26} \sin ^{2} \varphi\left(3 \cos ^{2} \varphi-\sin ^{2} \varphi\right)+\left(\Delta C_{22}\right.\right.\right. \\
& \left.\left.\sin ^{2} \varphi-\Delta C_{11} \cos ^{2} \varphi\right) \cos \varphi \sin \varphi+\Delta\left(C_{12}+2 C_{66}\right) \cos \varphi \sin \varphi \cos 2 \varphi\right] \sin ^{3} \theta+ \\
& {\left[\Delta C_{14} \cos \varphi\left(\cos ^{2} \varphi-2 \sin ^{2} \varphi\right)+3\left(\Delta C_{24} \sin \varphi-\Delta C_{15} \cos \varphi\right) \sin \varphi \cos \varphi+\right.} \\
& 2 \Delta C_{46} \sin \varphi\left(2 \cos ^{2} \varphi-\sin ^{2} \varphi\right)+\Delta C_{25} \sin \varphi\left(2 \cos ^{2} \varphi-\sin ^{2} \varphi\right)+2 \Delta C_{56} \cos \varphi \\
& \left.\left(\cos ^{2} \varphi-2 \sin ^{2} \varphi\right)\right] \cos \theta \sin ^{2} \theta+\left[\Delta\left(C_{36}+2 C_{45}\right) \cos 2 \varphi-\Delta\left(C_{13}+2 C_{55}\right) \sin \varphi\right. \\
& \left.\left.\left.\cos \varphi+\Delta\left(C_{23}+2 C_{44}\right) \sin \varphi \cos \varphi\right] \cos ^{2} \theta \sin \theta+\left[\Delta C_{34} \cos \varphi-\Delta C_{35} \sin \varphi\right] \cos ^{3} \theta\right\}\right\} \text {. }
\end{aligned}
$$


Where $\pi \square$ s the incidence angle; $\square M$ is the azimuth angle; $\kappa \square \square(\mathbb{D} \| \mathbb{m} \in \mathbb{s}$ s the ratio between $S$-wave and $\mathrm{P}$-wave velocities in the isotropic reference medium; $U[$ [is the background density; ' $U$ is the average density contrast across the interface;

$$
\begin{aligned}
& K \bigsqcup \square \sqrt{1 \square N^{2} \sin ^{2} T}, Z \square \square \\
& N \sin ^{2} T \square \cdot \square \square \cos T \text { and } K \square \square \\
& N \cos T \square \cdot \square \square \cdot C_{i j}
\end{aligned}
$$

is the average elastic constants contrast across the two media defined for

$$
\text { ' } C_{i j} \frac{C_{i j}^{\square \square} \square C_{i j}^{\square \square}}{2} .
$$

Where $C_{i j}^{[\mathrm{r}}$ indicates the transmission medium elastic tensor and $C_{i j}^{\square \square}$ is the elastic tensor in the medium of incidence, $i, j \quad 1, \cdots, 6$, in the standard reduced notation (HELBIG, 1994). The equations (1) was presented previously by Vavrycuk and Psencik (1998) and the equations (2) and (3) where also derived in Jílek (2002) in a somewhat different form. In order to derive the expression above, the polarization directions in the background media were chosen to be the SV and SH direction, which makes them more suitable when the medium of incidence has azimuthal symmetry. However, if degenerate perturbations theory can be used to compute more suitable polarization directions for shear waves (JECH; PSENCIK, 1989).

\section{INVERSION PROBLEM}

Using the equation (1) - (3) the inversion problem is reduced to the solution of a linear system:

$$
\mathrm{r}=\$ \mathrm{C}^{0}, M T \square
$$

Where $\mathbf{r}$ is the vector containing the observations $R_{q P q P}, R_{q S_{1} q P}, R_{q S_{2} q P} \square \mathbf{p}$ is the vector containing the density and elastic parameters contrasts and the matrix $\$ C^{0}, M T \square$ depends only on the background medium and the directions of the incident $q P$ wave.Based on SVD analysis of $\mathbf{A}$, multiazimuthal data is required to produce stable estimates . 3-D VSP experiments (LEANEY; SAYERS; MILLER, 1999) might provide this kind of data. The vector $\mathbf{p}$ is organized as bellow:

$$
\begin{aligned}
& \$ \mathrm{p}_{1} \quad C_{11} \mathrm{p}_{2} \quad \text { ' }\left[C _ { 1 2 } \square 2 C _ { 6 6 } \square \mathrm { p } _ { 3 } \quad ' \quad \left[C_{13} \square 2 C_{55} \square\right.\right. \\
& \left.. . \mathrm{p}_{4} \quad C_{22} \mathrm{p}_{5} \quad \text { ' } C_{23} \square 2 C_{44}\right] \quad \mathrm{p}_{6} \quad C_{33} \text {, } \\
& \text { " } \mathrm{p}_{7}{ }^{\prime} C_{44} \mathrm{p}_{8}{ }^{\prime} C_{55} \quad \mathrm{p}_{9}{ }^{\prime} C_{14} \text {. } \\
& . . \mathrm{p}_{10}{ }^{\prime} C_{15} \mathrm{p}_{11} \quad C_{16} \quad \mathrm{p}_{12} \quad C_{24} \text {. } \\
& \text {.. } \mathrm{p}_{13} \quad{ }^{\prime} C_{25} \mathrm{p}_{14} \quad C^{\prime} C_{26} \quad \mathrm{p}_{15} \quad C_{34} \text {; } \\
& { }^{\circ} \mathrm{p}_{16} \quad{ }^{\prime} C_{35} \mathrm{p}_{17} \quad{ }^{\prime} C_{36} \quad \mathrm{p}_{18} \quad C_{45} \text {. } \\
& \text { (ब) } \mathbb{p}_{19}{ }^{\prime} C_{46} \mathrm{p}_{20} \quad{ }^{\prime} C_{56} \quad \mathrm{p}_{21} \quad \rho / \rho^{0} \text { ' }
\end{aligned}
$$

For estimate of the parameters $\mathrm{p}$ we assume:

- weak impedance contrast, weak anisotropy;

- the medium of incidence is isotropic and coincides with the background media used for linearization.

For the estimation of fractures orientation we assume that the fractured medium behaves as an effective TI medium with its axis of symmetry perpendicular to the plane of fractures.

Under these assumptions, our goal is to estimate the orientation of the symmetry axis from the elastic parameters estimated from inversion. If the axis of symmetry is not aligned with one of the coordinate axis the plane of symmetry containing the axis forms an angle < Q Q vith the $x_{3}$ (Figure 1). This angle can be determined from the relation:

$$
\tan 2<\frac{2 \square C_{16} \square C_{26} \square}{\square C_{22} \square C_{11} \square}
$$

Unfortunately two angles have the same tangent $<$ and $<\mathbb{} \mid \mathbb{}[$. Rotating the elastic parameters estimated by the negative of one of these angles aligns the symmetry plane containing the tilted axis along the $x_{1}$ or $x_{2}$ axis. We can always choose the rotation, which align the symmetry plane containing the tilted axis along the $x_{1}$ axis and use the expression below to determine the dip angle 4

$$
\tan 24 \frac{2 \square C_{15} \square C_{35} \square}{\square C_{11} \square C_{33} \square}
$$

Under our assumptions, dip angle can be estimated from the inversion results except by the same ambiguity as before, i.e., 4 or $40 \$$ WI Whis ambiguity can be resolved rotating the parameter by the negative of these values and observing the differences $C_{11} \square C_{22}$ and $C_{33} \square C_{22}$. If the first difference is zero the axis of symmetry is aligned along $x_{3}$ and the dip angle is $4 \square \square S \square[$ btherwise $C_{33} \square C_{22}$ is zero and the axis is aligned along $x_{1}$ and the dip angle is 4 . It is always possible to perform this rotation, all the combination of elastic parameters required to perform this rotation are 
estimated from inversion. If the axis of symmetry coincides with one of the coordinate axis the algorithm fails. In this case orientation can be determined using the alternatives:

a) If $C_{22} \quad C_{33}$ and $C_{44} z C_{55}$ the axis is along $x_{1}$.

b) If $C_{11} \quad C_{33}$ and $C_{44} z C_{55}$ the axis is along $x_{2}$.

c) If $C_{11} \quad C_{22}$ and $C_{44} z C_{55}$ the axis is along $x_{3}$.

The resolution and stability of the inversion was evaluated using SVD analysis and numerical simulations. For the simulations several synthetic data sets were computed using the exact expressions for the reflection coefficients. Each synthetic data set was contaminated by Gaussian noise using 100 random seeds to initialize the random number generator. These data were inverted and the mean and standard deviations of the parameters used to evaluate stability.

\section{EXAMPLES}

The elastic parameters and the orientation the axis symmetry was estimated the of inversion from (1), (2) and (3) joins for two models.
The synthetic data set was generated solving the Zoeppritz equations (GOMES, 1999). The azimuth range is from $0^{\circ}$ to $360^{\circ}$ with $15^{\circ}$ intervals and the incidence angle varies from $0^{\circ}$ to $30^{\circ}$ with $1^{\circ}$ intervals. This data set was contaminated with different level Gaussian random noise of amplitude of $5 \%$ to $20 \%$ of the mean absolute value of the observations. The 100 data sets, each with a different noise contamination, were inverted. Both models have weak contrast ' UTD ' DDII EEGre smaller than 10\% and weak anisotropy.

In the first model the top medium is an isotropic $\rho=2.65 \mathrm{~g} / \mathrm{cm}^{3} \alpha=4.00 \mathrm{~km} / \mathrm{s} \mathrm{e} E=2,31 \mathrm{~km} / \mathrm{s}$. The bottom medium is TI with horizontal axis and its density is $p=2.5 \mathrm{~g} / \mathrm{cm}^{3}$ and its elastic tensor is:

Table 1 presents the average and standard deviations of the numerical simulation results,

The parameters ' $C_{11}, ' C_{12} \square 2 C_{66} \square$ ' ' $C_{13} \square 2 C_{55} \square$ ' $C_{22}$, ' $\square C_{23} \square 2 C_{44} \square$ ' $C_{33},{ }^{\prime} C_{44},{ }^{\prime} C_{55}$ and ' uा presented a relative error lower then $15 \%$ which characterizes a stable estimation. The remaining parameters, $\mathrm{p}_{9}-\mathrm{p}_{20^{\prime}}$ have very small mean $\left(10^{\square 4}\right)$ and the relative error cannot be computed. These results holds

Tabela 1 - Resultado da simulação numérica. São mostrados os valores exato, estimativa média e erro percentual dos parâmetros de $\mathrm{p}_{1}$ à $\mathrm{p}_{8}$ e $\mathrm{p}_{21}$ e dos parâmetros elásticos (em GPa). 0 nível de ruído nos dados é de 10\% do valor da máxima observação.

Table I- Numerical simulation results. Exact value, mean and the relative error of the estimated values for $\mathrm{p}_{1} \square \mathrm{p}_{8}, \mathrm{p}_{21}$ and elastic parameters (in GPa) in the transmitted medium. The data noise level is $10 \%$ of the observations maximum value.

\begin{tabular}{|c|c|c|c|c|c|c|c|}
\hline $\mathbf{( p )}$ & Extac & Mean & Error & $C_{i j}$ & Exact & Mean & Error \\
\hline$\Delta C_{11}$ & -0.0682 & -0.0632 & $1.75 \%$ & $C_{11}$ & 31.10 & 31.93 & $0.65 \%$ \\
\hline$\Delta\left(C_{12}+2 C_{66}\right)$ & -0.0439 & -0.0423 & $4.38 \%$ & $C_{12}+2 C_{66}$ & 35.13 & 35.60 & $0.5 \%$ \\
\hline$\Delta\left(C_{13}+2 C_{55}\right)$ & -0.0439 & -0.04261 & $1.17 \%$ & $C_{13}+2 C_{55}$ & 35.13 & 34.55 & $0.74 \%$ \\
\hline$\Delta C_{22}$ & -0.0119 & -0.0095 & $14.23 \%$ & $C_{22}$ & 40.43 & 40.73 & $0.54 \%$ \\
\hline$\Delta\left(C_{23}+C_{44}\right)$ & -0.0120 & -0.0121 & $3.59 \%$ & $C_{23}+2 C_{44}$ & 40.41 & 39.71 & $0.65 \%$ \\
\hline$\Delta C_{33}$ & -0.0119 & -0.01273 & $1.57 \%$ & $C_{33}$ & 40.43 & 39.90 & $0.07 \%$ \\
\hline$\Delta C_{44}$ & -0.0017 & -0.0017 & $3.39 \%$ & $C_{44}$ & 13.86 & 13.69 & $0.35 \%$ \\
\hline$\Delta C_{55}$ & -0.0107 & -0.0107 & $1.35 \%$ & $C_{55}$ & 12.38 & 12.17 & $0.39 \%$ \\
\hline$\Delta \rho / \rho^{0}$ & -0.01 & -0.008 & $4.9 \%$ & $\rho$ & 2.60 & 2.61 & $0.079 \%$ \\
\hline
\end{tabular}

for data noise level lower than $20 \%$. We must use (9) in order to estimate the orientation of the symmetry axis. The difference between $C_{22}$ and $C_{33}$ is smaller than the difference between these parameter and $C_{11}$. Noticing also the difference between $C_{44}$ and $C_{55}$, we conclude the medium is II with horizontal axis. The results are the same for $20 \%$ noise level.
In the second model the top medium is isotropic $u \notin 2.60 \mathrm{~g} / \mathrm{cm}^{3}, D \notin 4.600 \mathrm{~km} / \mathrm{s}$ and $E \notin 2.810 \mathrm{~km} / \mathrm{s}$. The bottom medium is a sandstone, its elastic tensor is TI with vertical axis and its Thomsen parameters (THOMSEN, 1986) are $U$ Z $2.50 \mathrm{~g} /$ $\mathrm{cm}^{3}, D \neq 4.476 \mathrm{~km} / \mathrm{s}$ and $E=2.841 \mathrm{~km} / \mathrm{s}, H \neq 0.097$, $d=0.091, J=0.051$. This medium was rotated of $60^{\circ}$ 
anticlockwise around $x_{3}$ axis and after that rotated of $30^{\circ}$ anticlockwise around the new $x_{2}$ axis (see Figure 1).

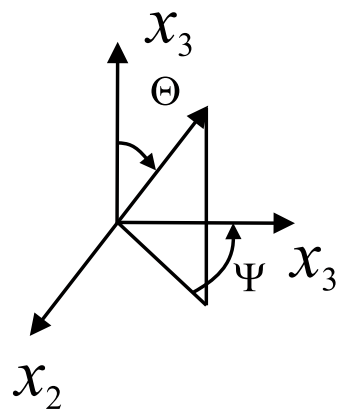

Figura 1 - Eixos coordenados. 0 ângulo < mede 0 azimute e 0 ângulo 4 [Tede a incidência.

Figure 1 - Coordinate axis. The angle $<$ [1; the azimuthal and the angle 4 is the incidence.

The Figures 2(a), 3(a), 4(a) present the stereogram of the exact corresponding stereogram computed from the mean of the parameters synthetic data for each wave type. Figures 2(b), 3(b), 4(b) present the estimated from 100 numerical simulations.

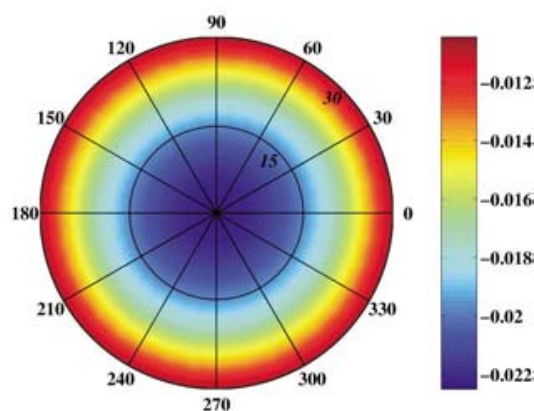

(a) Exact $\mathrm{R}_{\mathrm{qPP}}$

(a) $R_{\mathrm{qPqP}}$ exato

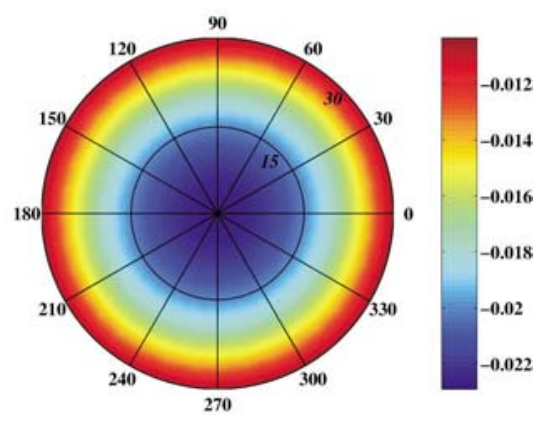

(b) $\mathrm{R}_{\mathrm{gPqP}}$ of the inverted model.

(b) $\mathrm{R}_{\mathrm{qPqP}}$ obtido a partir do meio estimado.

Figure 2 - Stereogram for the $\mathrm{R}_{\mathrm{qP}}$ Figura 2- Estereograma do coeficiente $R_{q P q P}$

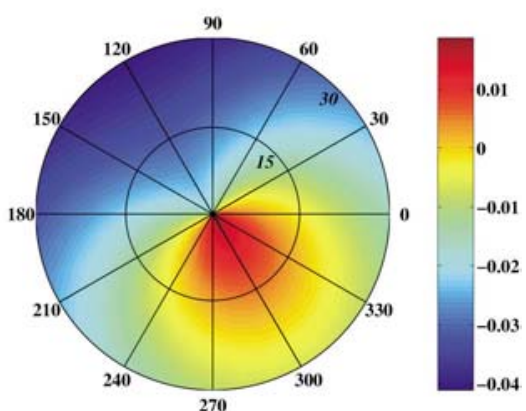

(a) Exact $\mathrm{R}_{\mathrm{qS} \mathrm{L}} \mathrm{P}^{\mathrm{p}}$

(a) $\mathrm{R}_{\mathrm{q} \mathrm{S}_{\mathrm{q}} \mathrm{P}}$ exato

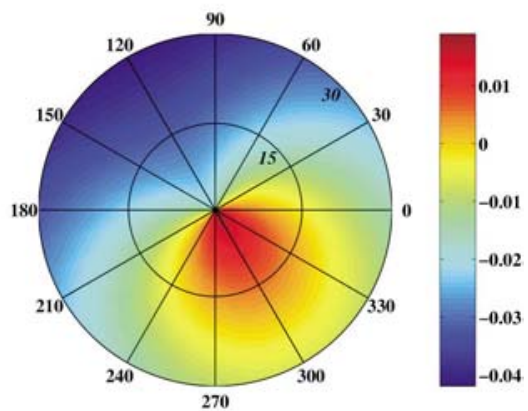

(b) $\mathrm{R}_{\mathrm{qS}_{1 \mathrm{q}} \mathrm{P}}$ of the inverted model.

(b) $\mathrm{R}_{\mathrm{qS}, \mathrm{qP}}$ obtido a partir do meio estimado

Figure 3 - Stereogram for the $\mathrm{R}_{\text {as.ap }}$ Figura 3 - Estereograma do coeficiente $R_{q \zeta q P}$ 


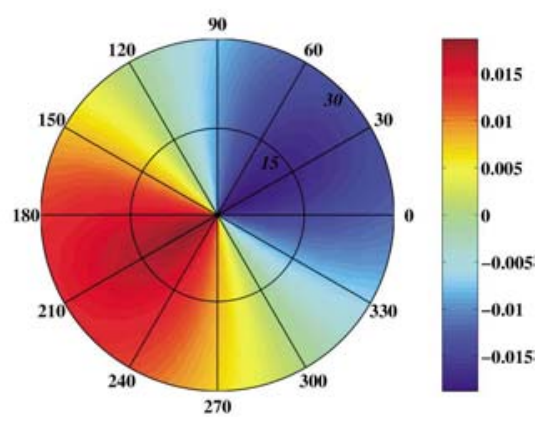

(a) Exact $\mathrm{R}_{\mathrm{qS}_{2} \mathrm{qP}}$.

(a) $\mathrm{R}_{\mathrm{qS}_{2} \mathrm{qP}}$ exato

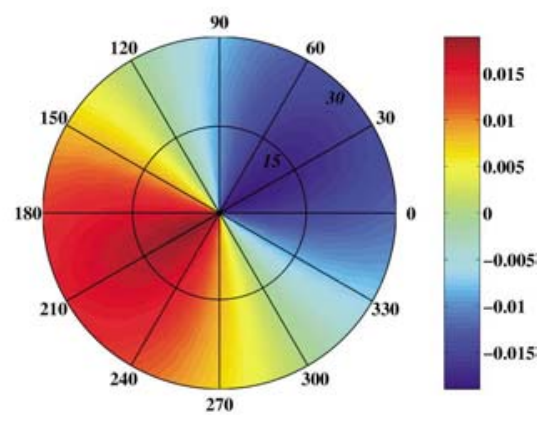

(b) $\mathrm{R}_{\mathrm{qS}_{2} \mathrm{qP}}$ of the inverted model.

(b) $\mathrm{R}_{\mathrm{qS}_{2} \mathrm{qP}}$ obtido a partir do meio estimado.

Figure 4 - Stereogram for the $\mathrm{R}_{\mathrm{aS}}$ Figura 4- Estereograma do coeficiente $R_{q \mathcal{q}_{2} q P}$

The symmetry of the $R_{P P}$ stereogram indicates its insensitivity to the dip of fractures. However, the SVD shows that $R_{q P q P}$ data is required to estimate the fractures dip. The estimated models fit the data with maximum residual of the order of $10^{\square 3}$ for every data set. The results of the numerical simulations for this model for 10\% noise level are presented in Table 2 which shows for the exact value of the $p$, its the average of the estimated, the ratio of the of the standard deviations. The results of the numerical simulations for this model for several noise levels are presented in Table 3 the of the average of the estimates of the symmetry axis azimuth and dip and the ratio of the standard deviation of the estimation over their average value.

The SVD analysis and the relative error of the estimated parameters in numerical simulations show that, although parameters

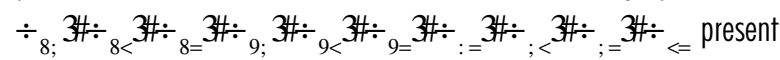
instability, the estimates of the symmetry axis orientation is stable. Since the recovery of the orientation depends on nonlinear functions of the parameters SVD analysis can not be applied to determine stability.

\section{CONCLUSIONS}

Several tests were performed with models with weak impedance contrast and weak anisotropy and also with models that violated some of these assumptions. Also different azimuth rages and incidence angles were used. From these test we drew the following:

1. $R_{q P q P^{\prime}} R_{q S_{1} \mathrm{PP}}$ and $R_{q S_{2} \mathrm{qP}}$ are required to recover the orientation from multiazimuthal AVO data only.

2. The minimum azimuth interval to recover stable estimates of orientations is $M]=30$.

3. The minimum incidence angle range is $T=30$.

4. Though the estimates of elastic parameters contrasts vary during the simulations, the estimates of the orientation angles are reliable for moderate noise levels $(<10 \%)$.

5. The estimates of fractures strike is more sensitive to noise than the fractures dip.

6. The estimates are accurate only for models with weak impedance contrast and weak anisotropy.

We presented an algorithm to estimate fractures orientation using multiazimuthal AVO analysis. Reflection coefficients of $R_{q P q P^{\prime}} R_{q S_{1} q P}$ and $R_{q S_{2} q P}$ are needed to determine the fractures dip. Though the assumption of an effective $\mathrm{Tl}$ behavior for fractures is restrictive, its validity can be checked from the symmetries of the elastic tensor derived from the inverted parameters. For a weak TI medium and weak impedance contrast, the estimates of fractures orientation are unique and stable for moderate noise levels. 
Tabela 2 - Resultado da simulação numérica. Valor exato, estimativa média e erro percentual dos parâmetros.

0 nível de ruído nos dados é de $10 \%$ do maior valor das observações.

Table 2- Numerical simulation results. Exact value, estimated mean value and relative error of the parameters. The data noise level is $10 \%$ of the observations maximum value.

\begin{tabular}{|c|c|c|c|}
\hline Param (p) & Extac Value & Mean & Error \\
\hline$\Delta C_{11}$ & 0.019 & 0.021 & $9.42 \%$ \\
\hline$\Delta\left(C_{12}+2 C_{66}\right)$ & 0.016 & 0.017 & $11.22 \%$ \\
\hline$\Delta\left(C_{13}+2 C_{55}\right)$ & 0.002 & 0.003 & $32.49 \%$ \\
\hline$\Delta C_{22}$ & 0.013 & 0.013 & $13.63 \%$ \\
\hline$\Delta\left(C_{23}+2 C_{44}\right)$ & 0.001 & 0.001 & $88.11 \%$ \\
\hline$\Delta C_{33}$ & -0.013 & -0.013 & $2.26 \%$ \\
\hline$\Delta C_{44}$ & -0.002 & -0.002 & $10.85 \%$ \\
\hline$\Delta C_{55}$ & -0.001 & -0.001 & $18.76 \%$ \\
\hline$\Delta C_{14}$ & -0.002 & -0.002 & $49.74 \%$ \\
\hline$\Delta C_{15}$ & 0.005 & 0.005 & $37.23 \%$ \\
\hline$\Delta C_{16}$ & 0.003 & 0.003 & $23.48 \%$ \\
\hline$\Delta C_{24}$ & -0.009 & -0.008 & $19.66 \%$ \\
\hline$\Delta C_{25}$ & 0.001 & 0.001 & $77.69 \%$ \\
\hline$\Delta C_{26}$ & 0.003 & 0.003 & $26.72 \%$ \\
\hline$\Delta C_{34}$ & -0.008 & -0.008 & $0.38 \%$ \\
\hline$\Delta C_{35}$ & 0.005 & 0.005 & $0.65 \%$ \\
\hline$\Delta C_{36}$ & 0.0003 & 0.001 & $81.68 \%$ \\
\hline$\Delta C_{45}$ & 0.0006 & 0.0007 & $21.46 \%$ \\
\hline$\Delta C_{46}$ & 0.002 & 0.002 & $50.86 \%$ \\
\hline$\Delta C_{56}$ & -0.003 & -0.003 & $30.85 \%$ \\
\hline$\Delta \rho / \rho^{o}$ & -0.02 & -0.02 & $2.55 \%$ \\
\hline
\end{tabular}

Tabela 3 - Resultado da simulação numérica para diferentes níveis de ruído. 0 desvio-padrão da média das estimativas é mostrado para indicar estabilidade. Table 3- Numerica/ simulation results for different noise levels. The ratio of the standard deviation of the estimates over the mean value is also presented to indicate the stability.

\begin{tabular}{|c|c|c|c|c|}
\hline Noise Level & Fract. Azimuth $\left(\right.$ Exact $\left.\Psi=60^{\circ}\right)$ & Deviation & Fract. Dip (Exact $\left.\Theta=30^{\circ}\right)$ & Deviation \\
\hline $5 \%$ & $60.05^{\circ}$ & $\pm 2.51^{\circ}$ & $29.43^{\circ}$ & $\pm 1^{\circ}$ \\
\hline $10 \%$ & $60.79^{\circ}$ & $\pm 5.38^{\circ}$ & $29.31^{\circ}$ & $\pm 1.42^{\circ}$ \\
\hline $20 \%$ & $58.89^{\circ}$ & $\pm 10^{\circ}$ & $28.48^{\circ}$ & $\pm 7.35^{\circ}$ \\
\hline
\end{tabular}




\section{Acknowledgments}

The authors acknowledge the financial support of the Project FINEP/CTPETRO/UFPA.

\section{REFERENCES}

BERETTA, M. M.; BERNASCONI, G.; DRUFUCA, G. AVO and AVA inversion of fractured reservoir characterization. Geophysics, [S.I.], v. 67, n. 1, p. 300-306, 2002.

GOMES, E. N. S. Reflectivity of $P$ waves in anisotropic media. Thesis (Master)-Department of Mathematics, Universidade Federal do Pará, Belém, 1999. In portuguese.

et al. Linearization of $\mathrm{qP}$ wave reflection coefficients in anisotropic media. Brazilian Journal of Geophysics, [S.I.], v. 19, n. 1, p. 48-60, 2001. In portuguese.

HELBIG, K. Foundations of anisotropy for exploration seismics. Oxford: Pregamon, 1994. (Handbook of Geophysical Exploration., v. 22) HUDSON, J. A. Wave speeds and attenuation of elastic waves in material containing cracks. Geophys. J. R. astr Soc, [S.I.], v. 64, p. 133-150, 1982.
JECH, J.; PSENCIK, I. First-order perturbation method for anisotropic media. Geophys. J. Int., [S.I.], v. 99, p. 369-376, 1989.

JilLEK, P. Converted PS-wave reflection coefficients in weakly anisotropic media. Pure and Applied Geophysics, [S.I.], n. 7-8, p. 1527-1562, 2002.

LEANEY,W. S., SAYERS, C. M.; MILLER, D. E. Analysis of multiazimuthal VSP data for anisotropy and AVO. Geophysics, [S.I.], v. 64, n. 4, p. 1172-1180, 1999.

PEREZ, M. A., GIBSON, R. L.; TOKSOZ, N. Detection of fracture orientation using azimuthal variation of P-wave AVO responses. Geophysics, [S.I.], V. 64, p. 1253-1265, 1999.

RÜGER, A.; TSVANKIN, I. Another perspective on AVO crossplotting. The Lead Edge, [S.I.], v. 16, n. 9, p. 1233-1237, 1997.

SCHOENBERG, M.; SAYERS, C. Seismic anisotropy of fractures. Geophysics, [S.I.], v. 60, p. 204-211, 1995.

THOMSEN, L. Weak elastic anisotropy. Geophysics, [S.I.], v. 51, n. 10, p. 1954-1966, 1986.

VAVRYCUK, V.; PSENCIK, V. PP-wave reflection coefficients in weakly anisotropic elastic media. Geophysics, [S.I.], v. 63, n. 6, p. 2129-2141, 1998.

\section{NOTES ABOUT THE AUTHORS}

Ellen de Nazaré Souza Gomes é formada em Licenciatura Plena em Ciências com Habilitação em Matemática (Universidade da Amazônia-Belém/PA,1990). Mestrado em Matemática (Universidade Federal do Pará-UFPA/1999) e Doutorado em Geofísica (UFPA/2003). É Professora da Universidade Federal do Pará desde 1997, no Departamento de Matemática, Campus de Castanhal. Atualmente é Professora do Departamento de Geofísica desta mesma Universidade. Áreas de interesse: anisotropia e modelagem sísmica.

Jessé Carvalho Costa é formado em Física (UFPA/1983) Mestre e Doutor em Geofísica (UFPA/1987, 1993 respectivamente). Summer Student na Schlumberger Cambridge Research em 1991 e 1992. Estágio de pós-doutoramento no Departamento de Geofísica na Universidade de Stanford (1994-1996) e Visiting Assistent Professor no Departamento de Geofísica da Universidade de Stanford (1995). É professor da Universidade Federal do Pará desde 1989, no Departamento de Física, de 1989/2003. Atualmente é professor do Departamento de Geofísica desta mesma Universidade. Áreas de interesse: anisotropia, modelagem sísmica e tomografia.

João dos Santos Protázio é formado em Matemática (UFPA/1972). Mestre em Matemática (PUC-RJ/1976). Doutor em Geofísica (UFPA/1994). Estágio de pósdoutoramento no Departamento de Matemática na Universidade Estadual de Campinas-UNICAMP. Foi pesquisador no Laboratório Nacional de Computação Científica - LNCC (1985-1987). Foi professor auxiliar e assistente na Pontifícia Universidade Católica do Rio de Janeiro - PUC (1973-1979). Foi professor da Universidade Federal do Pará, de 1973-2003. Atualmente é professor e coordenador do Curso de Licenciatura em Matemática da Escola Superior Madre Celeste-ESMAC. Áreas de interesse: anisotropia, modelagem sísmica.

Ivan A. Simões Filho é Geólogo pela Universidade de Nancy (França) e Doutor em Geofísica pela Universidade Federal da Bahia (UFBA). Foi professor de Geofísica de Reservatórios da Universidade Estadual de Campinas (UNICAMP) entre 1992 e 2003, onde coordenou o Programa de Pós-Graduação em Geoengenharia de Reservatórios e foi coordenador Associado do Centro de Estudos do Petróleo. Entre 1998 e 2002 foi superintendente de Promoção de Licitações da Agência Nacional do Petróleo (ANP) e entre 1999 e 2003 foi vice-presidente da Sociedade Brasileira de Geofísica (SBGf). Desde 2003 é Associado Sênior da Gaffney, Cline \& Associates (GCA), uma empresa de consultoria internacional em petróleo e gás natural. Membro da SBGF, IBP, SEG, EAGE e AAPG, publicou vários trabalhos em revistas científicas e técnicas no Brasil e no exterior e orientou vários alunos de pós-graduação. Fluente em português, inglês, francês e espanhol, Ivan reside atualmente em Houston (Estados Unidos), de onde coloca sua experiência à disposição dos clientes da GCA em projetos de petróleo e gás natural em diversos países das Américas, África, Europa, Oceania e Oriente Médio. 